\title{
Gallbladder Cancer Clinical TNM Finding v7
}

National Cancer Institute

\section{Source}

National Cancer Institute. Gallbladder Cancer Clinical TNM Finding v7. NCI Thesaurus.

Code C90212.

A clinical finding about one or more characteristics of gallbladder cancer, following the rules of the TNM AJCC V7 classification system. The clinical evaluation usually depends on the results of ultrasonography, computed tomography, and magnetic resonance cholangiopancreatography. Clinical staging may also be based on findings from surgical exploration (laparoscopic or open) when the main tumor mass is not resected. (from AJCC 7th Ed.) 